Jurnal Muttaqien, Vol. 1. No. 1 Juli 2020, 56 - 73

\title{
Manajemen Konflik dalam Rumah Tangga Isteri yang Bekerja
}

\author{
Sofia Gussevi \\ STAI DR. KHEZ. Muttaqien Purwakarta, Indonesia \\ sofiagussevi@staimuttaqien.ac.id
}

\section{Kata kunci: \\ Manajemen \\ Konflik \\ rumah tangga \\ Isteri bekerja}

\begin{abstract}
ABSTRAK
Penelitian ini dilatarbelakangi dari hasil observasi awal penulis yaitu gugatan cerai oleh isteri kepada suaminya mendominasi kasus perceraian yang terjadi di Pengadilan Agama Purwakarta. Ini terjadi pada mayoritas isteri yang bekerja di luar rumah. Berbeda dengan hal itu, di Perum Citra Permata Sakinah banyak isteri yang bekerja di luar rumah seperti di kantor pemerintahan, swasta, pabrik dan lainnya yang terikat dengan waktu yang sudah ditentukan. Walaupun mereka terikat dengan waktu tertentu, bahkan isteri yang bekerja di pabrik yang terikat dengan tiga sift yaitu sift pagi, siang dan malam tetapi mereka tidak mengalami permasalahan yang berarti, apalagi sampai kepada perceraian. Penelitian ini bertujuan untuk mengetahui konflik yang terjadi dalam rumah tangga isteri yang bekerja dan untuk mengetahui manajemen konflik yang diterapkan dalam rumah tangga isteri yang bekerja tersebut. Metode yang digunakan adalah metode kualitatif. Berdasarkan analisis hasil penelitian menunjukkan bahwa bentuk konflik yang terjadi dalam rumah tangga isteri yang bekerja Perum Citra Permata Sakinah berupa perdebatan/pertengkaran dan tidak saling tegur sapa dengan pasangan. Konflik yang terjadi dalam rumah tangga tersebut disebabkan antara lain karena perbedaan pendapat, kecemburuan pasangan, keadaan ekonomi rumah tangga serta faktor eksternal: pihak ketiga, orang tua serta lingkungan. Selanjutnya konflik yang terjadi dalam rumah tangga tersebut dapat mendatangkan dampak negatif antara lain terhambatnya komunikasi antar pihak yang berkonflik, terganggunya kerjasama dalam rumah tangga, serta timbulnya rasa ketidakpuasan dalam berumah tangga. Selain itu juga dapat berdampak positif di antaranya memandang bahwa konflik merupakan nikmat dari Allah SWT., penyesuaian diri dengan lingkungan rumah tangga, lebih berhati-hati dalam bertindak di kemudian hari, serta sebagai langkah intropeksi diri dalam rumah tangga. Selanjutnya manajemen konflik yang diterapkan isteri yang bekerja yaitu dengan cara pendekatan terhadap hal yang melatarbelakangi konflik tersebut, bermusyawarah mencari solusi baik dengan pasangan maupun melibatkan pihak ketiga misalnya orang tua, berdiam diri mengintrospeksi kesalahan sendiri yang mengakibatkan konflik tersebut muncul, serta saling pengertian terhadap kebiasaan dari masing-masing pasangan. Dengan demikian, gaya manajemen konflik yang diterapkan yaitu gaya kolaborasi.
\end{abstract}

\section{A. Pendahuluan}

Dalam menjalani kehidupan perkawinan sebagai suami isteri, membentuk keluarga yang bahagia dan kekal jelas tidak segampang yang dibayangkan. Keluarga bahagia bukan berarti keluarga yang diam tanpa masalah, namun lebih kepada adanya keterampilan mengelola konflik yang terjadi di dalamnya.

Konflik merupakan masalah yang dapat menyebabkan pertengkaran, perselisihan, atau benturan di antara kedua belah pihak. Jika konflik tidak diatasi sedini mungkin dengan 
disertai solusi yang baik, maka akan menimbulkan masalah yang jauh lebih buruk dari sebelumnya. Terjadinya konflik dalam rumah tangga merupakan suatu hal yang wajar, dan setiap pasangan suami isteri harus memahami dan mengerti faktor penyebab dari konflik tersebut.

Sumber konflik perkawinan dapat berasal dari status isteri yang bekerja. Misalnya ketika pekerjaan di luar rumah dianggap isteri sebagai hal penting bagi perkembangan potensinya, sedangkan suami menganggap bahwa kedekatan suami isteri akan berkurang dan pengasuhan anak akan terabaikan apabila isteri bekerja di luar rumah. Demikian juga terjadi angka perceraian meningkat disebabkan oleh pertentangan antara suami dan isteri yang keduanya sama-sama bekerja.

Mengenai perceraian ini, gugatan cerai isteri kepada suaminya mendominasi kasus perceraian di Kabupaten Purwakarta, Jawa Barat. Faktor ekonomi disebut-sebut menjadi penyebab utama kaum hawa lebih memilih tidak ingin berlama-lama mengarungi bahtera rumah tangganya. Hal ini terungkap berdasarkan data yang ada di Kantor Pengadilan Agama Purwakarta. Sepanjang tahun 2015 laporan perkara di Pengadilan Agama Purwakarta mengenai cerai gugat mencapai 895 perkara, sedangkan perkara cerai gugat yang diputus sebanyak 844 perkara. Jumlah cerai gugat ini berbanding terbalik dengan jumlah cerai talak, sepanjang tahun 2015 Pengadilan Agama Purwakarta menerima 334 perkara dan perkara yang diputus sebanyak 285 perkara $^{1}$.

Penyebab utama kasus cerai gugat dilakukan para isteri didominasi masalah ekonomi. Kemudian selingkuh dan terjadinya Kekerasan Dalam Rumah Tangga (KDRT). "Artinya dari data yang ada memang kasus cerai gugat masih menempati urutan pertama. Disusul di urutan kedua kasus cerai talak yang diajukan suami. Meski demikian, angka perceraian di Purwakarta masih rendah dibanding Subang, Karawang dan Indramayu," ujar Hj. N. Kesih, S.Ag. bidang Panitera Muda Hukum di Pengadilan Agama Purwakarta².

"Analisa saya, alasannya ekonomi. Penghasilan isteri lebih besar dari suaminya. Atau isteri bekerja sedangkan suaminya menganggur," urai Ruhiat yang juga kerap menjadi kuasa hukum ibu rumah tangga menggugat cerai suaminya. Dia menambahkan, "kelompok pemohon cerai gugat dan cerai talak berasal dari kalangan masyarakat umum dan buruh pabrik, mereka rata-rata yang usia perkawinan muda atau yang berumah tangga di bawah 10-5 tahun" jelasnya ${ }^{3}$.

Dari data serta hasil wawancara yang penulis lakukan di Pengadilan Agama Purwakarta tersebut menunjukkan bahwa rumah tangga yang isteri bekerja sebagai buruh atau karyawan pabrik yang banyak mengajukan cerai gugat. Pada tahun 2018 ketika penulis menjadi pembimbing mahasiswa Praktek Profesi Lapangan (PPL) lagi di Pengadilan Agama Purwakarta, penulis juga menemukan permasalahan yang sama yaitu rumah tangga yang isteri bekerja sebagai buruh atau karyawan pabrik banyak mengajukan cerai gugat.

Berkaitan dengan hal di atas, isteri yang bekerja inilah yang menjadi fokus penulis dalam penelitian ini. Penulis telah melakukan observasi awal di Perum Citra Permata

\footnotetext{
${ }^{1}$ N. Kesih, Panitera Muda Hukum PA Purwakarta, Wawancara Mendalam, Purwakarta, 03 Mei 2016

${ }^{2}$ Ibid.

${ }^{3}$ Ruhiat, Praktisi Hukum di PA Purwakarta, Wawancara Mendalam, Purwakarta, 03 Mei 2016
} 
Sakinah RT 014 RW 006 Desa Babakancikao Kecamatan Babakancikao Kabupaten Purwakarta. Perum Citra Permata Sakinah RT 014 RW 006 Desa Babakancikao ini terdiri dari 77 Kepala Keluarga (KK), hampir 75\% isteri bekerja. Ada yang bekerja sebagai karyawan pabrik, bekerja di lembaga pemerintahan, buka warung di rumah, onlineshop dan lain sebagainya. Tetapi isteri bekerja yang dimaksud dalam tulisan ini adalah isteri yang memang bekerja di luar rumah dan terikat dengan waktu tertentu. Dari 77 Kepala Keluarga (KK) itu ada 30\% (23 orang) isteri bekerja di lembaga pemerintahan (ruang publik) dan lembaga swasta serta bekerja sebagai buruh atau karyawan di pabrik.

Bekerja di lembaga pemerintahan dan lembaga swasta terikat dengan waktu yang sudah ditentukan. Apalagi yang bekerja di pabrik yang jam kerjanya pun dikenai 3 shift (pagi, siang, dan malam), serta dengan jadwal libur yang bergantian dengan karyawan lain. Hal ini akan berimbas kepada keluarga mereka.

Melihat dari sisi wilayah, Purwakarta sendiri telah menjadi tempat industri yang baik, terbukti dengan adanya berbagai jenis pabrik yang memproduksi mulai dari jenis makanan, kemasan makanan, otomotif, elektronik, tekstil, sampai garment. Pabrik garment sangat di dominasi oleh kaum perempuan, tapi pabrik otomotif dan elektro biasanya lebih banyak memperkerjakan kaum laki-laki.

Banyak alasan yang menyebabkan seorang isteri memutuskan untuk bekerja, salah satunya karena ingin membantu ekonomi keluarga. Isteri merasa keluarganya perlu memperoleh income dari kedua belah pihak, sehingga isteri ambil bagian dalam segi ekonomi keluarga. Selain itu sebenarnya keinginan untuk mengaktualisasikan diri karena pendidikannya yang cukup tinggi juga menjadi alasan lain seorang isteri memutuskan bekerja.

Apabila dilihat dalam kenyataan yang terjadi di masyarakat, sebenarnya tidak semua isteri yang bekerja di luar rumah itu menjadi suatu masalah dan menjadi sumber konflik, sehingga berakhir dengan perceraian. Ada juga isteri sibuk bekerja di luar rumah, tetapi rumah tangganya tetap aman dan bahagia saja.

Dari uraian di atas, masalah dapat diidentifikasikan sebagai berikut: 1) tujuan perkawinan adalah membentuk keluarga yang bahagia dan kekal; 2) dalam menjalani rumah tangga, pasangan suami isteri akan menemui berbagai konflik yang terjadi; 3) konflik dalam rumah tangga ini lebih mungkin terjadi apabila isteri bekerja, apalagi bekerja di pabrik; 4) konflik dalam rumah tangga akan menimbulkan berbagai dampak; 5) setiap pasangan suami isteri diharapkan sebisa mungkin menghindari terjadinya per-ceraian.

Selanutnya rumusan masalah dalam penelitian ini adalah sebagai berikut: 1) apa konflik yang terjadi dalam rumah tangga isteri yang bekerja Perum Citra Permata Sakinah?; 2) bagaimana manajemen konflik yang diterapkan dalam rumah tangga isteri yang bekerja Perum Citra Permata Sakinah?; 3) adapun tujuan dari penelitian ini sesuai dengan masalah yang telah dirumuskan yaitu: 1) untuk mengetahui konflik yang terjadi dalam rumah tangga isteri yang bekerja Perum Citra Permata Sakinah; 2) untuk mengetahui manajemen konflik yang diterapkan dalam rumah tangga isteri yang bekerja Perum Citra Permata Sakinah. Selanjutnya kegunaan penelitian ini di antaranya: 1) hasil penelitian ini diharapkan bisa berguna untuk memahami, mengembangkan dan menemukan teori baru serta menjadi rujukan dalam melakukan penelitian selanjutnya terutama mengenai manajemen konflik 
dalam rumah tangga; 2) menambah wawasan peneliti mengenai manajemen konflik yang terjadi dalam rumah tangga isteri yang bekerja yang selanjutnya disebarkan ilmu ini kepada mahasiswa melalui mata kuliah Hukum Perdata Islam di Indonesia dan Peradilan Agama di Indonesia.

\section{B. Teori / Konsep}

\section{Konflik dan Manajemen Konflik}

\section{a. Konflik}

1) Definisi konflik

Konflik berasal dari bahasa Latin yaitu configure yang berarti saling memukul. Secara sosiologis, konflik diartikan sebagai proses sosial antara dua orang atau lebih (bisa juga kelompok), salah satu pihak berusaha menyingkirkan pihak lain dengan menghancurkannya atau membuatnya tidak berdaya. Konflik dilatarbelakangi oleh perbedaan ciri-ciri yang dibawa individu dalam suatu interaksi.

Perbedaan tersebut menyangkut ciri fisik, kepandai-an, pengetahuan, adat istiadat, keyakinan, dan sebagainya. Dengan dibawasertanya ciri-ciri individual dalam interaksi sosial, konflik merupakan situasi yang wajar dalam setiap masyarakat dan tidak satu masyarakat pun yang tidak pernah mengalami konflik antar anggotanya atau dengan kelompok masyarakat lainnya (Effendi, 2020, 2021). Konflik akan hilang bersama hilangnya masyarakat ${ }^{4}$. Keberadaan konflik akan bersifat destruktif ataukah konstruktif, sangat tergantung pada strategi yang digunakan untuk menanganinya.

2) Pandangan mengenai peran konflik ${ }^{5}$

a) Pandangan Tradisional (the Traditional View)

Pandangan ini menyatakan konflik itu hal yang buruk, sesuatu yang negatif, merugikan dan harus dihindari.

b) Pandangan Hubungan Manusia (the Human Relation View)

Pandangan ini menyatakan konflik dianggap sebagai peristiwa yang wajar terjadi dalam kelompok atau organisasi. Konflik dianggap sebagai sesuatu yang tidak dapat dihindari.

c) Pandangan Interaksionis (the Interactionist View)

Pandangan ini cenderung mendorong suatu kelompok atau organisasi agar terjadi konflik. Hal ini disebabkan suatu organisasi yang kooperatif, tenang, damai dan serasi cenderung menjadi statis, tidak aspiratif dan tidak inovatif.

3) Faktor terjadinya konflik ${ }^{6}$

\footnotetext{
${ }^{4}$ A. Rusdiana, Manajemen Konflik, (Bandung: CV. Pustaka Setia, 2015), 68

${ }^{5}$ Stephen P. Robbins, Perilaku Organisasi, Konsep, Kontroversi dan Aplikasi, Alih Bahasa: Hadyana Pujaatmaka, Edisi Keenam, (Jakarta: Perlindo, 1996), 122

${ }^{6}$ Rusdiana, Manajemen Konflik, 151
} 
a) Adanya perbedaan kepribadian, pendirian, perasaan atau pendapat antar individu yang tidak mendapat toleransi di antara individu tersebut sehingga perbedaan semakin meruncing dan mengakibatkan munculnya konflik pribadi.

b) Adanya perbedaan kebudayaan yang mempengaruhi perilaku dan pola pikir sehingga memicu lahirnya pertengkaran antar kelompok atau antar masyarakat.

c) Adanya perbedaan kepentingan atau tujuan di antara individu atau kelompok, baik pada dimensi ekonomi dan budaya maupun politik dan keamanan.

d) Adanya perubahan sosial yang relatif cepat yang diikuti oleh adanya perubahan nilai atau sistem sosial.

Dari paparan di atas maka dapat dipahami bahwa konflik tidak bisa lepas dari kehidupan suatu masyarakat karena konflik merupakan fenomena yang tidak dapat dihilangkan dalam interaksi sosial. (Effendi, 2020)

4) Strategi menghadapi konflik ${ }^{7}$

a) Contending. Contending yaitu pemecahan masalah secara win-lose solution yaitu meyelesai-kan masalah tanpa mempedulikan kepentingan pihak lain.

b) Problem Solving. Problem Solving artinya menyelesaikan masalah dengan mempedulikan kepentingannya sendiri dan pihak lain.

c) Yielding. Yielding yaitu dengan mengalah, menurunkan aspirasinya dan bersedia menerima "kekurangan" dari yang sebenarnya diinginkan.

d) Inaction. Inaction yaitu dengan diam, tidak melakukan apapun. Tiap-tiap pihak saling menunggu tindakan pihak lain.

e) Withdrawing. Withdrawing yaitu dengan menarik diri, memilih meninggalkan situasi konflik, baik secara fisik maupun psikologis.

\section{b. Manajemen konflik}

1) Definisi manajemen konflik

Secara etimologi manajemen berarti kepemimpinan, proses pengaturan, menjamin kelancaran jalannya pekerjaan dalam mencapai tujuan dengan pengorbanan sekecil-kecilnya. Dengan kata lain, manajemen secara singkat berarti pengelolaan ${ }^{8}$. Menurut Mary Parker Vollett sebagaimana dikutip oleh Siswanto Bedjo, manajemen merupakan seni dalam menyelesaikan pekerjaan melalui orang lain. Manajemen mempunyai pengertian sebagai proses perencanaan, pengorganisasian, pengarahan dan pengawasan usaha-usaha para anggota organisasi dan penggunaan sumber daya-sumber daya organisasi lain ${ }^{9}$.

${ }^{7}$ Ibid., 156

${ }^{8}$ M. Sastrapradja, Kamus Istilah Pendidikan dan Umum, (Surabaya: Bina Ilmu, 1981), 307

${ }^{9}$ Siswanto Bedjo, Organisasi Kepemimpinan dan Perilaku Administrasi, (Jakarta: Haji Masagung, 1990), 3 
Manajemen apabila dihubungkan dengan konflik maka manajemen konflik merupakan serangkaian aksi dan reaksi antara pelaku ataupun pihak luar dalam suatu konflik. Manajemen konflik termasuk pendekatan yang berorientasi pada proses yang mengarahkan pada bentuk komunikasi dari pelaku atau pihak luar. Manajemen konflik dapat melibatkan diri sendiri, kerjasama dalam memecahkan masalah atau pengambilan keputusan oleh pihak ketiga.

Manajemen konflik bersifat proaktif dan menekankan pada usaha pencegahan. Apabila fokus perhatiannya hanya ditujukan pada pencarian solusi untuk setiap konflik yang muncul, usaha itu adalah penanganan konflik, bukan manajemen konflik.

2) Tujuan manajemen konflik

Berkaitan dengan manajemen konflik, Fisher dkk $^{10}$ menggunakan istilah transformasi konflik secara lebih umum dalam menggambarkan situasi dan tujuan secara keseluruhan yaitu:

a) Pencegahan konflik bertujuan untuk mencegah timbulnya konflik yang keras.

b) Penyelesaian konflik bertujuan untuk mengakhiri perilaku kekerasan melalui persetujuan damai.

c) Pengelolaan konflik bertujuan untuk membatasi dan menghindari kekerasan dan men-dorong perubahan perilaku positif bagi pihak-pihak yang terlibat.

d) Resolusi konflik menangani sebab-sebab konflik dan berusaha membangun hubungan baru dan tahan lama di antara kelompok-kelompok yang berkonflik.

e) Transformasi konflik mengatasi sumber-sumber konflik sosial dan politik yang lebih luas dan berusaha mengubah kekuatan negatif dari peperangan menjadi kekuatan sosial dan politik yang positif.

Tahapan-tahapan di atas merupakan satu kesatuan yang harus dilakukan dalam mengelola konflik sehingga setiap tahap akan melibatkan tahap sebelumnya, misalnya pengelolaan konflik akan mencakup pencegahan dan penyelesaian konflik.

3) Gaya manajemen konflik

Menurut Winardi ${ }^{11}$, gaya dan intensi yang diwakili tiap-tiap gaya adalah sebagai berikut:

a) Tindakan Menghindari (Avoiding). Tindakan menghindari ini misalnya bersikap tidak kooperatif dan tidak asertif, menarik diri dari situasi yang berkembang dan bersikap netral dalam segala macam "cuaca".

b) Kompetisi atau Komando Otoratif. Gaya ini sering diasosiasikan dengan gertakan dalam hardball tactic dari para pemegang kekuasaan. Gaya ini dikatakan efektif apabila membutuhkan keputusan yang cepat.

${ }^{10}$ Fisher Simon, dkk., Mengelola Konflik: Keterampilan dan Strategi untuk Bertindak, Jakarta: The British Council, Zen Books, 2001), 7

${ }^{11}$ Winardi J., Motivasi dan Pemotivasian, (Jakarta: Raja Grafindo, 2008), 26 
c) Akomodasi dan Meratakan. Sikap ini misalnya bersikap kooperatif, tetapi tidak asertif, membiarkan keinginan pihak lain menonjol, meratakan perbedaan untuk memper-tahankan harmoni yang diciptakan secara buatan.

d) Kompromis. Bersikap cukup kooperatif dan asertif, tetapi tidak hingga tingkat ekstrem. Bekerja menuju arah pemuasan kepentingan parsial semua pihak yang ber-kepentingan, melaksanakan tawar-menawar untuk mencapai pemecahan "akseptable". Tetapi bukan pemecahan optimal, hingga tidak seorangpun merasa menang atau kalah secara mutlak.

e) Kolaborasi (kerja sama) atau Pemecahan Masalah. Kolaborasi adalah bersikap kooperatif atau asertif, berupaya mencapai kepuasan setiap pihak yang berkepentingan serta mencari dan memecahkan masalah hingga setiap orang mencapai keuntungan sebagai hasilnya.

\section{Posisi Perempuan dalam Perspektif Hukum Islam}

Al-Qur'an maupun al-Sunnab sangat memuliakan posisi perempuan. Hal ini terlihat dalam sejumlah ayat al-Qur'an dan hadits Nabi yang menjelaskan tentang para perempuan Anshar di Madinah pada masa Rasul. Mereka aktif dalam berbagai bidang kehidupan, di ranah publik maupun di ranah domestik. Al-Qur'an menggambarkan mengenai tipe ideal perempuan Islam (muslimah) sebagai pribadi yang memiliki kemandirian dalam berbagai bidang kehidupan ${ }^{12}$. Hal ini dapat terlihat dari posisi perempuan di antaranya:

a. Posisi perempuan sebagai anak

Islam sangat melarang semua bentuk pembunuhan bayi perempuan sebagaimana lazim terjadi di masa Jahiliyah. Bahkan al-Qur'an menyebutkan kelahiran bayi perempuan sebagai berita gembira dari Allah, oleh karena itu tidak pantas kehadirannya disambut dengan rasa malu seperti yang terjadi pada masa Jahiliyah. Hal ini terlihat dalam QS. al-Nabl (16): 58-59.

b. Posisi perempuan sebagai isteri

Posisi perempuan sebagai isteri sangat terhormat, Islam menjamin kesetaraan dengan pasangannya yaitu suami. Apresiasi Islam terhadap isteri juga terlihat dalam ayat yang berbicara tentang perkawinan. Contohnya ketika berbicara mengenai azas perkawinan, al-Qur'an dengan tegas menyatakan monogami adalah bentuk perkawinan yang adil, sebagai-mana terdapat dalam QS. al-Nisaa' (4): 3. dan dikuat dalam QS. al-Nisaa' (4): 129.

c. Posisi perempuan sebagai ibu

Islam sangat menghargai hak-hak reproduksi ibu. Seorang ibu tidak boleh mengalami penderitaan apalagi kematian akibat melakukan fungsi reproduksinya, seperti hamil dan melahirkan. Ketika seorang ibu melakukan tugas-tugas

12 Siti Musdah Mulia, Muslimah Sejati Menempuh Jalan Islami Meraih Ridha Ilabi, (Bandung: Marja, 2011), 137 
reproduksinya, suami wajib menyediakan segala yang dibutuhkan oleh isterinya. Bahkan, suami juga harus menjamin terpeliharanya jiwa dan emosi isteri ${ }^{13}$.

d. Posisi perempuan sebagai warga masyarakat

Posisi perempuan dalam kehidupan bermasyarakat dan bernegara memiliki sejumlah hak dan kewajiban. Tidak ada perbedaan antara perempuan dan laki-laki. Perintah Allah untuk berbuat adil dalam seluruh bidang kehidupan, baik dalam ranah domestik maupun publik, sangat tegas dan tandas ${ }^{14}$.

Berdasarkan uraian di atas, maka dapat dipahami bahwa dalam Islam itu tidak ada diskriminasi terhadap perempuan, posisinya sangat diakui dan diberi kebebasan. Tetapi kebebasan tersebut mempunyai batas tertentu yang justru ditetapkan oleh Islam untuk kebaikan perempuan itu sendiri. Mereka boleh aktif dalam berbagai bidang kehidupan, di ranah publik maupun di ranah domestik, asalkan mereka memahami dan melaksanakan hak dan kewajiban mereka.

\section{Hak dan Kewajiban Suami dan Isteri dalam Rumah Tangga}

a. Hak dan kewajiban suami isteri

Dalam Kompilasi Hukum Islam, hak dan kewajiban suami isteri ${ }^{15}$ dijelaskan secara rinci dalam Pasal 77 sebagai berikut:

1) Suami isteri memikul kewajiban yang luhur untuk menegakkan rumah tangga sakinah, mawaddah dan rahmah yang menjadi sendi dasar dari masyarakat.

2) Suami isteri wajib saling mencintai, hormat menghormati, setia dan memberi bantuan lahir batin yang satu kepada yang lain.

3) Suami isteri memikul kewajiban untuk mengasuh dan memelihara anak-anak mereka, baik mengenai pertumbuhan jasmani, rohani maupun kecerdasannya dan pendidikan agamanya.

4) Suami isteri wajib menjaga kehormatannya.

5) Jika suami atau isteri melalaikan kewajibannya, masing-masing dapat mengajukan gugatan kepada Pengadilan Agama.

Berkaitan dengan hak dan kewajiban suami isteri juga dijelaskan dalam Pasal 78

Mengenai hal ini, Abdul Rahmat Ghozali dalam bukunya Fiqh Munakahat mengemukakan hak bersama suami isteri ${ }^{16}$ antara lain :

1) Suami isteri dihalalkan saling bergaul mengadakan hubungan seksual.

2) Haram melakukan perkawinan yaitu isteri haram dinikahi oleh ayah suaminya, kakeknya, anaknya dan cucu-cucunya. Begitu juga ibu isterinya, anak perempuannya dan seluruh cucunya haram dinikahi oleh suaminya.

3) Hak saling mendapat waris akibat dari perkawinan yang sah.

${ }^{13}$ Ibid., 141

${ }^{14}$ Ibid

${ }^{15}$ Tim Redaksi Fokusmedia, Kompilasi Hukum Islam, (Bandung: Fokusmedia, t.th), 28

${ }^{16}$ Abdul Rahmat Ghozali, Fiqih Munakahat, (Jakarta: Kencana Prenada Media Group, 2003), 156 
4) Anaknya mempunyai nasab (keturunan) yang jelas bagi suami.

5) Kedua belah pihak wajib bergaul (berperilaku) yang baik, sehingga dapat melahirkan kemesraan dan kedamaian hidup.

b. Kewajiban suami terhadap isteri

Dalam Kompilasi Hukum Islam, kewajiban suami terhadap isteri ${ }^{17}$ dijelaskan secara rinci dalam Pasal 80 sebagai berikut :

1) Suami adalah pembimbing terhadap isteri dan rumah tangganya, akan tetapi mengenai hal-hal urusan rumah tangga yang penting-penting diputuskan oleh suami isteri bersama.

2) Suami wajib melindungi isterinya dan memberikan segala sesuatu kebutuhan hidup rumah tangga sesuai dengan kemampuannya.

3) Suami wajib memberikan pendidikan agama kepada isteri dan memberikan kesempatan belajar pengetahuan yang berguna dan bermanfaat bagi agama dan bangsa.

4) Sesuai dengan penghasilannya, suami menanggung:

a) Nafkah, kiswah dan tempat kediaman bagi isteri;

b) Biaya rumah tangga, perawatan dan biaya pengobatan bagi isteri dan anak;

c) Biaya pendidikan bagi anak.

5) Kewajiban suami terhadap isterinya seperti tersebut pada ayat (4) huruf a dan b di atas mulai berlaku sesuai ada tamkin sempurna dari isteri.

6) Isteri dapat membebaskan suaminya dari kewajiban terhadap dirinya sebagaimana tersebut pada ayat (4) huruf a dan b.

7) Kewajiban suami isteri sebagaimana dimaksud ayat (2) gugur apabila isteri nusyu\%:

Mengenai tempat kediaman juga merupakan kewajiban suami terhadap isteri sebagaimana diatur dalam Pasal 81

c. Hak suami terhadap isteri (kewajiban isteri terhadap suami)

Adapun kewajiban isteri yang terdapat dalam Undang-Undang Perkawinan pasal 34 diatur secara garis besar pada ayat $(2)^{18}$, dalam Kompilasi Hukum Islam diatur juga mengenai kewajiban isteri ${ }^{19}$ lebih rinci dalam Pasal 83 sebagi berikut:

1) Kewajiban utama bagi seorang isteri ialah berbakti lahir batin kepada suami di dalam batas-batas yang dibenarkan oleh hukum Islam

2) Isteri menyelenggarakan dan mengatur keperluan rumah tangga sehari-hari dengan sebaik-baiknya.

Kewajiban isteri terhadap suami ini juga dijelaskan dalam Pasal 84

${ }^{17}$ Tim Redaksi Fokusmedia, Kompilasi Hukum ..., 29

${ }^{18}$ Tim Redaksi Fokusmedia, Undang-Undang Perkawinan (Edisi Lengkap), (Bandung: Fokusmedia, 2016), 11

${ }^{19}$ Tim Redaksi Fokusmedia, Kompilasi Hukum..., 30 


\section{Metode Penelitian}

Pendekatan yuridis yaitu cara mendekati masalah dengan mendasarkan pada semua tata aturan perundang-undangan yang berlaku di Indonesia. Pendekatan normatif yaitu pendekatan yang menuju dan mengarah pada persoalan ditetapkannya sesuatu berdasarkan hukum Islam. Metode penelitian ini menggunakan metode kualitatif deskriptif yaitu penelitian untuk memahami fenomena tentang apa yang dialami oleh subjek penelitian, dengan cara deskripsi, dalam bentuk kata-kata dan bahasa ${ }^{20}$. Penelitian ini masuk dalam kategori metode penelitian kualitatif studi kasus. Studi kasus adalah salah satu metode penelitian ilmu-ilmu sosial ${ }^{21}$.

Penelitian ini dilaksanakan di Pengadilan Agama Purwakarta dan Perum Citra Permata Sakinah RT 014 RW 006 Ds. Babakancikao Kec. Babakancikao, Kab. Purwakarta bulan Agustus sampai bulan November tahun 2019. Responden (subjek penelitian) atau informan adalah orang yang mampu memberikan informasi tentang situasi dan kondisi latar belakang penelitian ${ }^{22}$. Responden dalam penelitian ini adalah antara lain hakim di Pengadilan Agama Purwakarta, Panitera Muda Hukum Pengadilan Agama Purwakarta, Praktisi Hukum di Pengadilan Agama Purwakarta, Isteri-isteri yang bekerja Perum Citra Permata Sakinah.

Adapun jenis data dalam penelitian dibagi dalam kata-kata dan tindakan, dokumentasi atau sumber data tertulis. Menurut Suharsimi Arikunto sumber data dalam penelitian ${ }^{23}$ adalah subjek darimana data diperoleh. Apabila peneliti menggunakan kuisioner (wawancara) dalam pengumpulan datanya, maka sumber data disebut responden. Apabila peneliti menggunakan teknik observasi, maka sumber datanya bisa berupa benda bergerak atau proses sesuatu. Sedangkan apabila peneliti menggunakan dokumentasi, maka dokumen atau catatan yang menjadi sumber data. Untuk selanjutna dilsakukan analsis mendalam terkait objek yang diteliti.

\section{Analisis Corak Pemikiran Hukum Teologi Asy'ariyyah}

1. Bentuk Konflik dalam Rumah Tangga Isteri yang Bekerja Perum Citra Permata Sakinah

Perdebatan hingga terjadi percekcokan biasanya ini terjadi karena tingkat emosi yang sama-sama meningkat, dan tidak ada yang mau mengalah, serta beranggapan bahwa dirinya-lah yang paling benar. Ketika keduanya cekcok adu mulut, mereka tidak sadar bahwa mereka berbicara dalam keadaan marah dan tidak akan bertemu dengan pemecahan masalah yang sedang dihadapi, justru akan menambah ketegangan di antara keduanya. Sebaiknya masing-masing pasangan sadar, ketika suaminya sedang emosi,

\footnotetext{
${ }^{20}$ Lexy J. Meleong, Metodelogi Penelitian Kualitatif, (Bandung: Remaja Rosdakarya, 2012), 4

${ }^{21}$ Robert K. Yin, Studi Kasus Desain dan Metode, (Jakarta: Rajawali Press, 2015), 1

${ }^{22}$ Moleong, Metodelogi Penelitian..., 97

${ }^{23}$ Suharsimi Arikunto, Prosedur Penelitian Suatu Pendekatan Praktek, (Jakarta: Rineka Cipta, 2006), 126
} 
lebih baik isteri jangan memancing hal-hal yang akan membuat suasana lebih kacau. Setelah suami selesai berbicara maka giliran isteri untuk berbicara.

Selanjutnya tidak saling tegur sapa dengan pasangan biasanya disebabkan rasa kecewa yang sangat mendalam. Saling diam ini mengakibatkan terhambatnya komunikasi antar pihak yang berkonflik. Rumah tangga yang baik adalah yang melakukan komunikasi dengan baik terhadap pasangannya. Tidak saling tegur sapa dengan pasangan ini juga akan mengganggu kerjasama dalam rumah tangga, maka sulit rasanya rumah tangga tersebut dapat berhasil mencapai tujuannya.

Bentuk konflik dalam rumah tangga isteri yang bekerja Perum Citra Permata Sakinah $^{24}$ antara lain:

1) Perdebatan/Pertengkaran

Perdebatan hingga terjadi percekcokan merupakan salah satu bentuk konflik yang terjadi dalam rumah tangga. Biasanya ini terjadi karena tingkat emosi yang sama-sama meningkat, tidak ada yang mau mengalah dan beranggapan bahwa dirinyalah yang paling benar serta sama-sama ingin menang sendiri.

2) Tidak saling tegur sapa dengan pasangan

Tidak saling tegur sapa dengan pasangan bisa terjadi karena kesalahan yang sudah beberapa kali dilakukan oleh pasangan dan berkali-kali pula pasangannya memaafkan. Sikap tidak menghargai keputusan pasangan dan terlalu mementingkan urusannya sendiri, semuanya itu sebagai pemicu konflik yang bentuk konfliknya tidak bertegur sapa dengan pasangannya yang akan membuat rumah tangga semakin tegang.

\section{Penyebab Terjadinya Konflik dalam Rumah Tangga Isteri yang Bekerja Perum} Citra Permata Sakinah

Mengenai penyebab terjadinya konflik diuraikan A. Rusdiana dalam bukunya Manajemen Konflike ${ }^{25}$, walaupun sebenarnya buku A. Rusdiana tersebut mengenai manajemen konflik dalam organisasi, hal ini juga dapat terlihat pada faktor terjadinya konflik dalam rumah tangga secara umum atau rumah tangga suami dan isteri yang sama-sama bekerja.

Konflik yang terjadi dalam rumah tangga, mulai dari menyatukan visi dan misi, ber-adaptasi dengan lingkungan pasangan, beradaptasi dengan keluarga pasangan dan ber-adaptasi dengan kebiasaan-kebiasaan pasangan dari sebelum menikah yang terbawa sampai setelah menikah. Apalagi konflik itu terjadi dalam rumah tangga isteri yang

\footnotetext{
${ }^{24}$ Isteri yang bekerja Perum Citra Permata Sakinah, Wawancara Mendalam, Purwakarta September-Oktober 2019

${ }^{25}$ Rusdiana, Manajemen Konflik, 151
} 
bekerja, maka hal itu juga dapat memperparah keadaan. Hal ini dikarenakan sebagian besar waktu isteri yang bekerja ini digunakan untuk berkerja, dan waktu untuk melaksanakan kewajibannya sebagai isteri dan ibu dalam rumah tangga menjadi berkurang.

Perbedaan yang terjadi dalam rumah tangga tidak bisa dihindari. Perlu waktu untuk menyadari dan menyikapi perbedaan itu. Sering kali kita mendengar seseorang mengakhiri pernikahannya dengan alasan "sudah tidak ada kecocokan lagi". Kata-kata ini jugalah yang sering diucapkan oleh seorang perempuan di depan pengadilan mengenai alasannya meng-gugat cerai suaminya ${ }^{26}$. Sebaiknya perbedaan bukan alasan seseorang harus mengakhiri rumah tangganya namun lebih kepada suami dan isteri mencari solusi terhadap konflik yang terjadi tersebut dan membuat manajemen yang baik dalam rumah tangganya, sehingga konflik yang muncul tidak mengakibatkan perceraian. Kalau dilihat konflik yang terjadi dalam rumah tangga isteri yang bekerja ini, yang sering terjadi adalah mengenai pengasuhan anak. Karena kesibukan pekerjaan isteri sekaligus ibu yang bekerja, seringkali kewajibannya terhadap anak terabaikan. Sebenarnya tidak ada salahnya juga minta bantuan kepada keluarga terdekat dalam pengasuhan anak ini, misalnya kepada orang tua atau saudara perempuan dari suami maupun isteri. Tetapi harus disadari juga, walaupun orang tua mau membantu dalam pengasuhan anak, pada dasarnya orang tua juga merasa lelah kalau peng-asuhan anak ini diserahkan sepenuhnya kepada mereka ${ }^{27}$.

Ketika seorang perempuan yang telah berumah tangga dan telah memiliki anak, kemudian memutuskan untuk bekerja maka dirinya harus mampu menjalankan peran ganda, baik peran sebagai isteri maupun peran sebagai ibu. Kalau isteri yang bekerja itu merasa tidak mampu menjalankan peran ganda tersebut, maka lebih baik mundur dari pekerjaan dan lebih mengutamakan pengasuhan $a_{n a k}{ }^{28}$. Karena keluarga adalah sekolah pertama bagi seorang anak dan ibu adalah guru yang utama yang akan mengajari norma-norma kepada anak untuk bersikap dan bertingkah laku dengan baik.

\footnotetext{
${ }^{26} \mathrm{Hal}$ ini penulis temukan pada waktu membimbing mahasiswa dalam pelaksanaan Praktek Profesi Lapangan di Pengadilan Agama Purwakarta. Dalam persidangan, ketika hakim menanyakan alasan kepada perempuan yang mengajukan gugat cerai, sering kali mengungkapkan dengan kalimat "sudah tidak cocok lagi Pak".

${ }^{27}$ Nenek Ica, Mertua Ira (Isteri yang Bekerja Perum Citra Permata Sakinah) Wawancara Mendalam, Purwakarta 20 Oktober 2019. Nenek Ica inilah yang mengasuh anak Ira ketika Ira dan suaminya berkerja.

${ }^{28}$ Mila dan Endah, Isteri yang Bekerja Perum Citra Permata Sakinah, Wawancara Mendalam, Purwakarta 22 September 2019. Pada waktu diwawancara mereka sudah berhenti bekerja.
} 
Berkaitan dengan isteri yang bekerja, kalau dilihat dari perspektif hukum Islam, sebenarnya tidak ada larangan kepada isteri untuk bekerja di luar rumah. Tetapi yang harus menjadi dasar dan yang harus disadari oleh isteri yang bekerja itu adalah kewajibannya sebagai isteri dan kewajibannya sebagai ibu tidak terabaikan disebabkan kesibukannya dalam bekerja, karena itu merupakan tugas dan fungsi yang utama isteri dalam rumah tangga.

Penyebab terjadinya konflik dalam rumah tangga isteri yang bekerja Perum Citra Permata Sakinah ${ }^{29}$ antara lain:

1) Perbedaan pendapat/argument

Perbedaan pendapat ini biasanya terjadi karena persepsi yang berbeda dalam melihat masalah. Hal ini dipengaruhi oleh latar belakang pendidikan, kepribadian dan juga pengalaman yang mereka alami selama ini, serta pola asuh keluarga dari masing-masing pasangan. Perbedaan pendapat yang sering terjadi dalam rumah tangga adalah mengenai anak.

2) Kecemburuan pasangan

Sifat cemburu dapat lahir dari sikap tidak percaya diri, adanya kekhawatiran dan ketakutan yang berlebihan terhadap pasangan suami atau isteri yang akan tidak setia atau berpindah ke lain hati. Ketidakpercayaan ini akan menimbulkan permasalahan dalam rumah tangga.

3) Keadaan ekonomi rumah tangga Uang bisa menyebabkan terjadinya konflik dalam keluarga. Terlalu sedikit uang, hampir dan selalu menimbulkan krisis dalam rumah tangga. Terlalu banyak uangpun menyebabkan gangguan fisik dan non fisik, seperti susah tidur dan lainnya. Untuk menghindari konflik mengenai ekonomi keluarga maka perlu adanya sikap saling percaya dan jujur antara suami dan isteri.

4) Faktor eksternal, di antaranya:

a) Hadirnya pihak ketiga

Pihak ketiga dalam hal ini bukan hanya dalam arti "selingkuh" tetapi juga orang yang berniat dan berusaha mengganggu keutuhan rumah tangga.

b) Orang tua

Tindakan orang tua dapat menimbulkan masalah dalam rumah tangga anaknya, misalnya orang tua yang over protektif dan orang tua yang biasa memanjakan anaknya. Menghadapi orang tua yang seperti itu perlu diberikan pemahaman atau dengan cara setelah menikah tidak tinggal bersama orang tua, baik dengan orang tua suami ataupun orang tua isteri.

c) Lingkungan

Lingkungan merupakan bagian yang terpenting dan mendasar dari kehidupan manusia. Lingkungan sangat besar pengaruhnya terhadap 
perilaku seseorang, begitupun dengan kehidupan rumah tangga. Pasangan yang baru memulai kehidupan menjadi sepasang suami isteri tentunya harus bisa beradaptasi dengan lingkungan barunya.

\section{Dampak Konflik dalam Rumah Tangga Isteri yang Bekerja Perum Citra Permata Sakinah}

Berdasarkan hasil penelitian terlihat bahwa konflik yang terjadi dalam rumah tangga isteri yang bekerja Perum Citra Permata Sakinah selain mendatangkan dampak negatif, sebenarnya juga dapat mendatangkan dampak positif.

Dengan demikian, walaupun banyak terjadi konflik dalam rumah tangga isteri yang bekerja, hendaknya jangan bersikap pesimis tetapi harus optimis dalam menjalani kehidup-an, harus berusaha mencari solusi yang terbaik secara bersama-sama dengan pasangan. Jangan menyerah dengan keadaan, apalagi sampai memutuskan dengan jalan perceraian. Kalaupun terjadi konflik dalam rumah tangga, tetap memandang bahwa konflik merupakan nikmat dari Allah SWT. dan berprasangka baik terhadap takdir Allah. Pada setiap masalah pasti ada jalan keluarnya. Allah tidak sertamerta mempertemukan kita dengan pasangan kita kalau tidak ada takdir baik dari Allah untuk kita.

Dampak konflik dalam rumah tangga isteri yang bekerja Perum Citra Permata Sakinah $^{30}$ antara lain:

1) Dampak positif terjadinya konflik dalam rumah tangga di antaranya:

a) Memandang bahwa konflik merupakan nikmat dari Allah SWT., berprasangka baik terhadap takdir-Nya.

b) Penyesuaian diri dengan lingkungan rumah tangga.

c) Lebih berhati-hati dalam bertindak di kemudian hari.

d) Sebagai langkah intropeksi diri dalam rumah tangga.

2) Dampak negatif terjadinya konflik dalam rumah tangga di antaranya : :

a) Terhambatnya komunikasi antar pihak yang berkonflik.

b) Terganggunya kerjasama dalam rumah tangga.

c) Timbulnya rasa ketidakpuasan dalam berumah tangga.

\section{Dampak Konflik dalam Rumah Tangga Isteri yang Bekerja Perum Citra} Permata Sakinah

Dalam membina rumah tangga, manajemen konflik dibutuhkan untuk meminimalisir konflik yang terjadi, dimulai dari menyadari akan hak dan kewajiban sebagai suami isteri serta cerdas membaca situasi rumah tangga. Apabila terjadi konflik, suami atau isteri harus membicarakannya dengan pasangannya terlebih dahulu, baru kemudian melibatkan keluarga yaitu orang tua atau mertua, maupun saudara. Ataupun dapat juga dengan meminta pen-dapat kepada orang yang dipercaya dapat menyelesaikan masalah yang mereka hadapi. Hal ini sebagaimana terdapat dalam firman Allah yang berbunyi: 


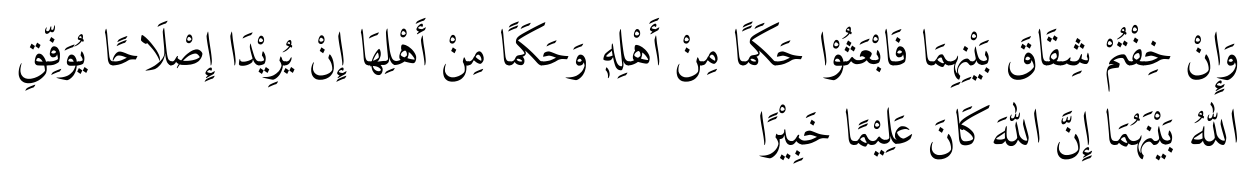

Artinya : Dan jika kamu khawatirkan ada persengketaan antara keduanya, Maka kirimlah seorang hakam (pendamai) dari keluarga laki-laki dan seorang hakam dari keluarga perempuan. jika kedua orang hakam itu bermaksud mengadakan perbaikan, niscaya Allah memberi taufik kepada suami-isteri itu. Sesunggubnya Allab Maha mengetabui lagi Maha Mengenal. ${ }^{31}$

Dalam hukum Islam masing-masing pasangan dituntut untuk menyadari bahwa dalam pernikahan itu harus saling memberi dan menerima, saling membantu dan saling mem-pahami serta saling mengasihi dan saling menyayangi. Sebagaimana yang terdapat dalam firman Allah yang berbunyi:

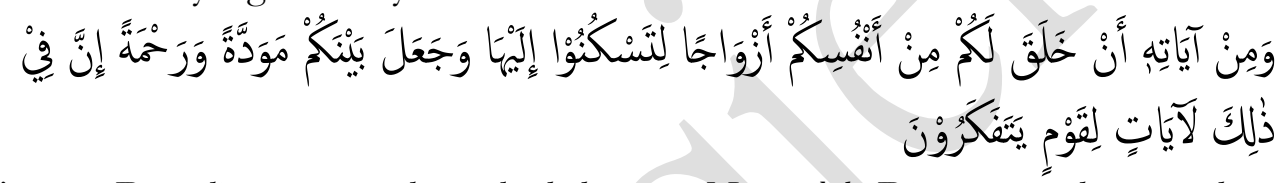

Artinya : Dan di antara tanda-tanda kekuasaan-Nya ialah Dia menciptakan untukmu isteri-isteri dari jenismu sendiri, supaya kamu cenderung dan merasa tenteram kepadanya, dan dijadikan-Nya di antaramu rasa kasib dan sayang. Sesunggubnya pada yang demikian itu benarbenar terdapat tanda-tanda bagi kaum yang berfikir. ${ }^{32}$

Dalam ayat di atas "...dan dijadikan di antara keduanya kasih dan sayang..." menunjukkan bahwa yang sangat dibutuhkan oleh suami dan isteri dalam rumah tangga adalah rasa saling mengasihi, menyayangi, mencintai, mengayomi, bekerja sama, sabar, bersikap lemah lembut, memahami serta mendahulukan kepentingan bersama dan tidak selalu menuntut hak.

Sedangkan gaya manajemen konflik seperti yang diungkapkan oleh Winardi J. dalam bukunya Motivasi dan Pemotivasian ${ }^{33}$, ada beberapa gaya manajemen konflik yaitu: Tindakan Menghindari (Avoiding), Kompetisi atau Komando Otoratif, Akomodasi dan Meratakan, Kompromis serta Kolaborasi (kerja sama) atau Pemecahan Masalah. Berdasarkan gaya manajemen konflik yang dipaparkan oleh Winardi J. tersebut, maka gaya manajemen konflik yang digunakan oleh isteri yang bekerja Perum Citra Permata Sakinah adalah gaya kolaborasi yaitu berupaya mencapai kepuasan setiap pihak yang berkepentingan, mencari dan memecahkan masalah sehingga setiap orang mencapai keuntungan sebagai hasilnya. Hal ini berarti isteri yang bekerja tersebut bersama-sama

${ }^{31}$ QS. al-Nisaa' (4) : 35

${ }^{32} \mathrm{QS}$. al-Rum $(30): 21$

${ }^{33}$ Winardi J., Motivasi dan Pemotivasian, 26 
dengan suaminya menyelesaikan konflik yang terjadi dalam rumah tangga mereka. Dalam menanggulangi konflik yang terjadi, isteri yang bekerja tersebut bersama suaminya melakukan pengelolaan konflik secara efektif.

Berkaitan dengan semakin meningkatnya angka cerai gugat yang terjadi di Pengadilan Agama Purwakarta, penulis menyimpulkan hal itu disebabkan karena suami atau isteri masih mempertahankan egonya masing-masing. Bisa juga disebabkan isteri yang bekerja yang mengajukan cerai gugat tersebut terbilang rata-rata yang usia perkawinan muda dan atau yang berumah tangga di bawah 10-5 tahun ${ }^{34}$. Sehingga manajemen konflik yang diterapkan belum maksimal dilaksanakan. Selain hal itu, cerai gugat ini juga disebabkan karena sekarang ini semakin tinggi tingkat pendidikan perempuan $^{35}$.

Dengan demikian, dapat dikatakan meningkatnya angka cerai gugat yang terjadi di Pengadilan Agama Purwakarta disebabkan manajemen konflik yang belum maksimal dilaksanakan masing-masing pasangan suami isteri, karena usia perkawinan muda dan atau yang belum lama berumah tangga. Alasan lainnya yaitu semakin tingginya tingkat pen-didikan perempuan sekarang ini.

Manajemen Konflik dalam Rumah Tangga Isteri yang Bekerja Perum Citra Permata Sakinah ${ }^{36}$ Jika terjadi konflik dalam rumah tangga isteri yang bekerja Perum Citra Permata Sakinah, maka yang mereka melakukan:

1) Mencari hal yang melatarbelakangi konflik tersebut.

2) Bermusyawarah mencari solusi baik dengan pasangan maupun melibatkan pihak ketiga biasanya orang tua.

3) Berdiam diri mengintropeksi kesalahan sendiri yang mengakibatkan konflik tersebut muncul.

4) Saling memahami dan saling pengertian terhadap perbedaan dan kebiasaan dari masing-masing pasangan.

\section{E. Simpulan}

Berdasarkan uraian sebelumnya, maka dapat diambil kesimpulan sebagai berikut: Pertama, Konflik yang terjadi dalam rumah tangga isteri yang bekerja Perum Citra Permata Sakinah berupa perdebatan/pertengkaran dan tidak saling tegur sapa dengan pasangan.

\footnotetext{
${ }^{34} \mathrm{Hal}$ ini penulis dapatkan ketika wawancara dengan Praktisi Hukum di Pengadilan Agama Purwakarta sebagaimana telah penulis jelaskan dalam BAB sebelumnya.

${ }^{35}$ Nurdin (Hakim Pengadilan Agama Purwakarta), hal ini disampaikan dalam pemaparan materi yang diadakan di Ruang Sidang Utama Pengadilan Agama Purwakarta dalam acara Praktek Profesi Lapangan mahasiswa Prodi Ahwal al-Syakhsiyyah STAI DR. KHEZ. Muttaqien di Pengadilan Agama Purwakarta.

${ }^{36}$ Ibid.
} 
Dan konflik tersebut disebabkan oleh banyak hal, di antaranya perbedaan pendapat, kecemburuan pasangan, keadaan ekonomi rumah tangga serta faktor eksternal: pihak ketiga, orang tua serta lingkungan sekitar yang membentuk karakter pasangan tersebut. Selanjutnya konflik yang terjadi dalam rumah tangga tersebut dapat mendatangkan dampak negatif antara lain terhambatnya komunikasi antar pihak yang berkonflik, ter-ganggunya kerjasama dalam rumah tangga serta timbulnya rasa ketidakpuasan dalam berumah tangga. Selain mendatangkan dampak negatif, sebenarnya konflik dalam rumah tangga tersebut dapat berdampak positif juga di antaranya memandang bahwa konflik merupakan nikmat dari Allah SWT., penyesuaian diri dengan lingkungan rumah tangga, membuat rumah tangga lebih harmonis, lebih berhati-hati dalam ber-tindak di kemudian hari, serta sebagai langkah introspeksi diri dalam rumah tangga. Kedua, Manajemen konflik yang diterapkan isteri yang bekerja Perum Citra Permata Sakinah dalam rumah tangga mereka yaitu dengan cara pendekatan terhadap hal yang melatar-belakangi konflik tersebut, mereka bermusyawarah mencari solusi baik dengan pasang-an maupun melibatkan pihak ketiga biasanya orang tua, berdiam diri mengintrospeksi kesalahan sendiri yang mengakibatkan konflik tersebut muncul, serta saling memahami dan saling pengertian terhadap kebiasaan dari masing-masing pasangan. Dengan demikian, gaya manajemen konflik yang diterapkan yaitu gaya kolaborasi. Isteri yang bekerja tersebut bersama-sama dengan suaminya menyelesaikan konflik yang terjadi dalam rumah tangga mereka sehingga keinginan mereka tercapai. *

\section{DAFTAR PUSTAKA}

Arikunto, Suharsimi, 2006. Prosedur Penelitian Suatu Pendekatan Praktek, Jakarta: Rineka Cipta Bedjo, Siswanto, 1990. Organisasi Kepemimpinan dan Perilaku Administrasi, Jakarta: Haji Masagung

Effendi, M. R. (2020). Pertalian Agama dalam Pilkada DKI Jakarta Tahun 2017. Jurnal Mibar Demokrasi, 19(2), 12-27. https://doi.org/10.21009/jimd.v19i02.14528

Effendi, M. R. (2021). Relasi Agama dan Masyarakat; Studi Tentang Interaksi Masyarakat Bandung Barat dan Jamaah Tabligh. Hayula, 5(1), 1-24. https://doi.org/https://doi.org/10.21009/hayula.005.1

Effendi, M. R., Kahmad, D., Solihin, M., \& Wibisono, M. Y. (2021). Relasi Agama dan Masyarakat: Studi Tentang Interaksi Masyarakat Bandung Barat dan Jamaah Tabligh. Hayula: Indonesian Journal of Multidisciplinary Islamic Studies, 5(1), 1-24. 
Effendi, M. R., \& Syafrudin, I. (2020). Pertalian Agama Pada Pilkada DKI Jakarta Tahun 2017. Jurnal Ilmiah Mimbar Demokrasi, 19(02), 12-27.

Ghozali, Abdul Rahmat, 2003. Fiqih Munakahat, Jakarta: Kencana Prenada Media Group Isteri-isteri yang bekerja Perum Citra Permata Sakinah, Wawancara Mendalam, Purwakarta September-Oktober 2019

J. Winardi, 2008. Motivasi dan Pemotivasian, Jakarta: Raja Grafindo

Moleong, Lexy J., 2005. Metodelogi Penelitian Kualitatif, Bandung: Remaja Rosdakarya

Mulia, Siti Musdah, 2011. Muslimah Sejati Menempub Jalan Islami Meraib Ridha Ilabi, Bandung: Marja

Muthiah, Aulia, Hukum Islam Dinamika Seputar Hukum Keluarga, Yogyakarta: Pustaka Baru

Mila dan Endah, Isteri yang Bekerja Perum Citra Permata, Wawancara Mendalam, Purwakarta 22 September 2019

Nenek Ica, Mertua Ira (Isteri yang Bekerja Perum Citra Permata Sakinah) Wawancara Mendalam, Purwakarta 20 Oktober 2019

N. Kesih, Panitera Muda Hukum PA Purwakarta, Wawancara Mendalam, Purwakarta, 03 Mei 2016

Ruhiat, Praktisi Hukum di PA Purwakarta, Wawancara Mendalam, Purwakarta, 03 Mei 2016

Press

Robbins, Stephen P., 1996. Perilaku Organisasi, Konsep, Kontroversi dan Aplikasi, Alih Bahasa: Hadyana Pujaatmaka, Edisi Keenam, Jakarta: Perlindo

Rusdiana, A., 2015. Manajemen Konflik, Bandung: CV. Pustaka Setia

Sastrapradja, M. 1981. Kamus Istilah Pendidikan dan Umum, Surabaya: Bina Ilmu

Simon, Fisher, dkk., 2001. Mengelola Konflik : Keterampilan dan Strategi untuk Bertindak, Jakarta: The British Council, Zen Books

Sugiyono, 2015. Metode Penelitian Pendidikan Pendekatan Kuantitatif, Kualitatif dan R \&D, Bandung: Alfabeta

Tim Redaksi Fokusmedia, 2016. Undang-Undang Perkawinan (Edisi Lengkap), Bandung: Fokusmedia

Tim Redaksi Fokusmedia, t.th. Kompilasi Hukum Islam, Bandung: Fokusmedia

Yin, Robert K., 2015. Studi Kasus Desain dan Metode, Jakarta: Rajawali Press 